\title{
ANALISIS PRODUKSI BERAS DI INDONESIA
}

\author{
Lim Sanny \\ Jurusan Manajemen, Fakultas Ekonomi dan Bisnis, Universitas Bina Nusantara \\ Jln. K.H. Syahdan No. 9, Palmerah, Jakarta Barat 11480 \\ lsanny@binus.ac.id, lsanny@yahoo.com
}

\begin{abstract}
Most of Indonesian still needs rice as a staple food. More and more quantity of people in a region will be increasing amount consumption of food in region, while decrease of rice field area that become different to public building or industrial affairs and economic transformation from agrarian affairs to nonagrarian affairs will be consequence rice production descend. Until now, domestic rice production was not able to meet its growing demand, so that Indonesia remains dependent upon rice import. This condition was made worse by conversion of fertile lowland in Java. Therefore, rice production growth was leveling-off. In the future, there should be some efforts to increase rice production, although land conversion is still going on. This study is aimed to assess the performance of lowland use, its contribution and prospect to increase rice production. The results showed that lowland is the main source of rice production. Another potential is improvement of intensification through promotion of intensification with integrated crops management. The implementation of these strategic policies should be supported by development and renovation of infrastructures as well as establishment of credit scheme to enable farmers to adopt modern technology.
\end{abstract}

Keywords: productivity, agricultural land, rice production

\begin{abstract}
ABSTRAK
Sebagian besar penduduk Indonesia masih membutuhkan beras sebagai kebutuhan pokoknya. Semakin bertambahnya jumlah penduduk suatu daerah akan meningkatkan besarnya konsumsi pangan suatu daerah sedangkan berkurangnya lahan persawahan yang berubah fungsi menjadi perumahan atau tempat industri dan juga transformasi ekonomi dari agraris ke non agraris akan mengakibatkan turunnya produksi padi. Hingga saat ini Indonesia belum mampu memenuhi kebutuhan beras dalam negeri sehingga masih tergantung pada impor. Kondisi ini diperburuk oleh adanya konversi lahan subur di Jawa sehingga pertumbuhan produksi padi melandai. Studi ini mencoba mengkaji kinerja pemanfaatan lahan sawah, kontribusi dan prospeknya dalam peningkatan produksi padi nasional. Hasil studi menunjukkan bahwa lahan sawah merupakan sumber utama produksi padi. Potensi lainnya ialah peningkatan mutu intensifikasi melalui penggunaan varietas unggul disertai dengan pengelolaan tanaman dan sumberdaya terpadu. Penerapan kebijakan ini harus didukung oleh pembangunan dan renovasi infrastruktur disertai penyediaan sumber modal agar memungkinkan petani mengadopsi teknologi maju.
\end{abstract}

Kata kunci: produktivitas, lahan pertanian, produksi padi 


\section{PENDAHULUAN}

Indonesia merupakan daerah yang memiliki potensi yang sangat baik pada sektor pertanian, sehingga Indonesia di tingkat internasional merupakan salah satu produsen sekaligus konsumen beras terbesar dunia di bawah Cina. Kondisi tersebut menuntut kreativitas dari masyarakat Indonesia untuk berkreasi supaya produksi padi Indonesia menjadi meningkat atau minimal stabil. Dengan kestabilan produksi, Indonesia dapat menjaga ketahanan pangan nasional.

Indonesia yang memiliki berbagai potensi dan permasalahan terkait dengan pangan, sehingga sangat menarik untuk dilakukan pengamatan. Pengembangan pertanian di lahan pasang surut merupakan perwujudan dan upaya pemanfaatan potensi alam secara optimal, penyeimbangan penduduk, pemerataan pembangunan, peningkatan produktivitas dan taraf hidup masyarakat. Pemanfaatan dan pengembangan lahan pasang surut secara optimal akan memberikan sumbangan besar terhadap pencapaian dan pelestarian swasembada pangan khususnya beras.

\section{Studi Pustaka}

BPS dan Deptan (1999) mendefinisikan luas panen merupakan luas lahan sawah yang biasa diambil hasilnya. Luas tanam merupakan luas lahan sawah yang ditanami. Sedangkan produktivitas merupakan hasil yang diperoleh tiap satuan luas, dan produksi merupakan suatu besaran berat yang mengukur hasil total padi yang diperoleh, juga merupakan hasil kali antara produktivitas dan luas panen.

Usaha tani padi menyediakan lapangan pekerjaan dan sebagai sumber pendapatan bagi sekitar 21 juta rumah tangga pertanian. Selain itu, beras juga merupakan komoditas politik yang sangat strategis sehingga produksi beras dalam negeri menjadi tolok ukur ketersediaan pangan bagi Indonesia (Suryana, 2002). Oleh karena itu, tidaklah mengherankan jika campur tangan pemerintah Indonesia sangat besar dalam upaya peningkatan produksi dan stabilitas harga beras. Kecukupan pangan (terutama beras) dengan harga yang terjangkau telah menjadi tujuan utama kebijakan pembangunan pertanian. Kekurangan pangan bias menyebabkan kerawanan ekonomi, sosial, dan politik yang dapat menggoyahkan stabilitas nasional.

Irawan (2003) melaporkan bahwa selama 1978-1998 sekitar 1,07 juta ha lahan (30,8\%) telah terkonversi menjadi lahan non pertanian. Selama periode yang sama, terdapat pembukaan sawah baru sekitar 0,91 juta ha. Namun, sejak krisis ekonomi yang berkepanjangan, pembukaan sawah baru hampir tidak mungkin karena keterbatasan dana pembangunan. Dengan demikian, adalah sangat sulit mempertahankan luas areal tanam padi di Jawa. Di lain pihak, sekitar 48\% padi ditanam di Jawa, mempunyai kontribusi produksi sekitar 58\% dari produksi padi nasional. Ini berarti bahwa konversi lahan di Jawa akan berpengaruh buruk terhadap produksi beras nasional dan dengan sendirinya memperlemah ketahanan pangan (Sudaryanto et al., 2006).

Machmud (2005) menjelaskan bahwa harga beras memiliki keunikan dalam proses penentuannya sehingga perlu kehati-hatian dalam menentukan harganya. Keunikan tersebut antara lain beras sebagai makanan pokok masyarakat Indonesia untuk meningkatkan kesejahteraan petani perlu adanya kenaikan harga beras, namun jika harga beras tinggi penduduk miskin akan meningkat. Keunikan yang lain meskipun pemerintah telah menaikkan harga dasar penjualan padi tetap saja petani akan miskin. Kajian lain yang dilakukan Bank Dunia (2004) menyimpulkan bahwa kenaikan harga beras hingga 33\% telah menyebabkan kenaikan angka kemiskinan sebanyak 3,1 juta orang. Kesimpulan ini berarti setiap kali ada 3 kenaikan harga beras akan terjadi pertambahan penduduk miskin. Sebaliknya, penurunan harga beras akan menurunkan angka kemiskinan, tetapi akan meningkatkan kemiskinan pada kelompok pertanian. 
Kajian lain yang dikeluarkan Ketua Divisi Ilmu Sosial International Rice Reserach Institute (IRRI), Mahbub Hosain (2006), menyimpulkan bahwa petani dan para pekerja lainnya di usaha pertanian kususnya padi akan terdorong untuk berusaha lebih giat ketika harga beras membaik sehingga proteksi pasar domestik akan memberikan jaminan perbaikan pada harga beras. Akibatnya, ekonomi desa akan bergerak begitu harga komoditas di desa mengalami perbaikan. Hosain mencontohkan, usaha tani padi di China mulai kurang menarik setelah harga beras selalu rendah.

Sihono (2007) menyimpulkan dalam penelitiannya tentang Deferensiasi Harga Beras di Indonesia Pasca Krisis Ekonomi, menyebutkan bahwa persediaan beras di tingkat pengepul (penebas) sangat mempengaruhi harga beras pada tingkat daerah, sedangkan musim juga berpengaruh signifikan terhadap harga beras karena jika musim kemarau hasil beras akan lebih baik jika dibandingkan pada musim penghujan. Namun, faktor yang paling berpengaruh terhadap harga beras adalah kebijakan impor beras oleh pemerintah. Dengan melihat fenomena yang terjadi di atas, maka penentuan harga beras di Indonesia harus hati-hati sehingga dalam mengamati dampak kebijakan penentuan harga beras harus melihat faktor-faktor yang mempengaruhinya. Akan makin jernih permasalahan tentang harga beras jika kita menangkap keluhan dari masyarakat dengan kita bertemu langsung dengan mereka.

Untuk menjaga ketersediaan beras di Indonesia, perlu ditingkatkan peran dari masyarakat dan pemerintah daerah guna menjaga ketersediaan beras di tingkat nasional. Salah satu cara untuk meningkatkan peran masyarakat guna menjaga ketersediaan beras pada tingkat daerah dan pedesaan adalah dengan tetap menanam padi dan meningkatkan hasil produksinya. Sedangkan peran pemerintah adalah menjaga ketersediaan bahan-bahan pendukung guna melakukan produksi beras. Ketersediaan beras akan mempengaruhi harga beras, selain itu harga beras juga dipengaruhi oleh harga barang lain serta kebijakan dari pemerintah (Agus, 2006).

Berbagai kebijakan untuk meningkatkan produksi padi seperti pembangunan sarana irigasi, subsidi benih, pupuk, dan pestisida, kredit usahatani bersubsidi, dan pembinaan kelembagaan usaha tani telah ditempuh. Demikian juga dalam pemasaran hasil, pemerintah mengeluarkan kebijakan Harga Dasar Gabah (HDG) atau Harga Dasar Pembelian Pemerintah (HDPP), untuk melindungi petani dari jatuhnya harga dibawah biaya produksi. Sementara itu, kebijakan impor dilakukan untuk memenuhi kebutuhan dalam negeri yang terus meningkat, dan agar harga beras terjangkau oleh sebagian besar konsumen. Campur tangan yang sangat besar dan bersifat protektif telah membuahkan hasil, yaitu tercapainya swasembada beras pada tahun 1984. Namun demikian, swasembada yang dicapai hanya sesaat. Secara umum, selama lebih dari tiga dekade produksi beras dalam negeri belum mampu memenuhi kebutuhan. Dengan kata lain, Indonesia hamper selalu defisit sehingga masih tergantung pada impor (Sudaryanto, 2006).

\section{METODE PENELITIAN}

Jenis penelitian yang digunakan adalah penelitian deskriptif. Metode penelitian yang digunakan adalah studi literatur. Penelitian ini dilakukan dengan cara membaca, mengumpulkan, mencatat, mempelajari buku, mempelajari penelitian sebelumnya yang relevan, informasi melalui internet serta sumber lainnya berupa teori dan yang mendukung penulisan laporan penelitian ini.

\section{HASIL DAN PEMBAHASAN}

Beras merupakan makanan sumber karbohidrat yang utama di kebanyakan Negara Asia. Negara-negara lain seperti di benua Eropa, Australia dan Amerika mengkonsumsi beras dalam jumlah 
yang jauh lebih kecil daripada negara Asia. Kebutuhan beras nasional tidak terpenuhi oleh produksi beras dalam negeri karena itu kita masih selalu mengimpor beras. Dengan memperhatikan hal di atas seharusnya agribisnis padi dapat menarik banyak para investor. Namun demikian, di lain pihak, harga beras sangat ditentukan pemerintah dan tidak dinamis seperti halnya tanaman hortikultur atau perkebunan sehingga umumnya petani padi sering merugi. Tanpa perubahan tata niaga beras dan pengurangan campur tangan pemerintah, agribisnis padi akan tetap tidak banyak diperhitungkan dan diminati oleh investor di bidang pertanian.

Peningkatan produksi padi masih merupakan prioritas dalam mendukung program ketahanan pangan dan agribisnis. Produksi padi terus dipacu untuk memenuhi kebutuhan pangan yang terus meningkat. Namun demikian, segala upaya untuk meningkatkan produksi selalu mendapat gangguan, antara lain berupa kekeringan, banjir, serangan hama, dan penyakit. Penggunaan pupuk secara rasional dan berimbang merupakan faktor kunci dalam peningkatan produksi padi. Sedangkan rekomendasi pupuk yang berlaku saat ini masih bersifat umum dan belum mempertimbangkan kandungan atau status hara tanah sehingga penggunaan pupuk tidak efisien.

Kenaikan produksi padi tahun 2009 terjadi di beberapa propinsi terutama di Jawa Barat, Jawa Timur, Jawa Tengah, Lampung, dan Sulawesi Selatan. Sedangkan penurunan produksi tahun 2009 terjadi di Sulawesi Tengah, Sulawesi Barat, Kalimantan Timur, dan Kalimantan Barat. Produksi padi tahun 2009 sebesar 64,33 juta ton Gabah Kering Giling (GKG). Dibandingkan produksi tahun 2008, terjadi peningkatan sebanyak 4,00 juta ton (6,64\%). Kenaikan produksi terjadi karena peningkatan luas panen seluas 550,61 ribu hektar (4,47\%) dan juga produktivitas sebesar 1,01 kuintal/hektar (2,06\%). Kenaikan produksi padi tahun 2009 tersebut terjadi di Jawa sebesar 2,49 juta ton (7,69\%) dan di luar Jawa sebesar 1,51 juta ton (5,42\%). Di Jawa, peningkatan produksi disebabkan oleh naiknya luas panen seluas 349,28 ribu hektar (6,08\%) dan produktivitas sebesar 0,86 kuintal/hektar (1,53\%). Demikian juga di luar Jawa, kenaikan produksi terjadi karena peningkatan luas panen seluas 201,33 ribu hektar (3,06\%), dan produktivitas sebesar 0,97 kuintal/hektar (2,28\%).

Tabel 1 Perkembangan Luas Panen, Produktivitas, dan Produksi Padi Menurut Wilayah 2008 - 2010

\begin{tabular}{|c|c|c|c|c|c|c|c|}
\hline \multirow{3}{*}{ URAIAN } & \multirow{3}{*}{2008} & \multirow{3}{*}{2009} & \multirow{3}{*}{2010} & \multicolumn{4}{|c|}{ Perkembangan } \\
\hline & & & & \multicolumn{2}{|c|}{ 2008-2009 } & \multicolumn{2}{|c|}{ 2009-2010 } \\
\hline & & & & Absolut & $\%$ & Absolut & $\%$ \\
\hline \multicolumn{8}{|l|}{ Luas Panen (ha) } \\
\hline Pulau Jawa & $5,742,270$ & $6,091,552$ & $6,039,392$ & 349,282 & 6.08 & 52,160 & -0.86 \\
\hline Luar Jawa & $6,585,155$ & $6,786,487$ & $6,852,357$ & 201,332 & 3.06 & 65,870 & 0.97 \\
\hline Indonesia & $12,327,425$ & $12,878,039$ & $12,891,749$ & 550,614 & 4.47 & 13,710 & 0.11 \\
\hline \multicolumn{8}{|l|}{ Produktivitas (ku/ha) } \\
\hline Pulau Jawa & 56.33 & 57.19 & 57.98 & 0.86 & 1.53 & 0.79 & 1.38 \\
\hline Luar Jawa & 42.49 & 43.46 & 43.6 & 0.97 & 2.28 & 0.14 & 0.32 \\
\hline Indonesia & 48.94 & 49.95 & 50.34 & 1.01 & 2.06 & 0.39 & 0.78 \\
\hline \multicolumn{8}{|l|}{ Produksi ( ton ) } \\
\hline Pulau Jawa & $32,346,997$ & $34,835,263$ & $35,018,342$ & $2,488,266$ & 7.69 & 183,079 & 0.53 \\
\hline Luar Jawa & $27,978,928$ & $29,494,066$ & $29,879,358$ & $1,515,138$ & 5.42 & 385,292 & 1.31 \\
\hline Indonesia & $60,325,925$ & $64,329,329$ & $64,897,700$ & $4,003,404$ & 6.64 & 568,371 & 0.88 \\
\hline
\end{tabular}

Sumber: BPS (Biro Pusat Statistik) 
Angka ramalan produksi padi tahun 2010 diperkirakan sebesar 64,90 juta ton Gabah Kering Giling (GKG) dibandingkan produksi tahun 2009, terjadi peningkatan sebanyak 568,37 ribu ton $(0,88 \%)$. Kenaikan produksi diperkirakan terjadi karena peningkatan luas panen seluas 13,71 ribu hektar $(0,11 \%)$ dan juga produktivitas sebesar 0,39 kuintal/hektar (0,78\%). Kenaikan produksi padi tahun 2010 tersebut diperkirakan terjadi di Jawa sebesar 183,08 ribu ton (0,53\%) dan di luar Jawa sebesar 385,29 ribu ton (1,31\%). Di Jawa, peningkatan produksi disebabkan oleh naiknya produktivitas sebesar 0,79 kuintal/hektar (1,38\%), sedangkan luas panen diperkirakan mengalami penurunan sebesar 52,16 ribu hektar (0,86\%). Sementara di luar Jawa, kenaikan produksi terjadi karena peningkatan luas panen seluas 65,87 ribu hektar (0,97\%) dan juga produktivitas sebesar 0,14 kuintal/hektar (0,32\%). Perkiraan kenaikan produksi padi tahun 2010 yang relatif besar terdapat di beberapa daerah terutama di Jawa Tengah, Sumatera Selatan, dan Kalimantan Selatan. Sedangkan perkiraan penurunan produksi tahun 2010 yang relatif besar terdapat di Jawa Barat dan Nusa Tenggara Barat. Berikut adalah pola panen padi per bulan dari tahun 2007-2009.

Tabel 2 Pola Panen Padi per Bulan dari Tahun 2007-2009

\begin{tabular}{|c|c|c|c|c|c|c|c|c|c|c|c|c|}
\hline \multicolumn{13}{|c|}{ Pola Panen Padi, 2007-2009 (ha) } \\
\hline & Jan & Feb & Mar & Apr & Mei & Jun & Jul & Agu & Sep & Okt & Nov & Des \\
\hline 2007 & 365,727 & 693,546 & $1,605,187$ & $2,229,079$ & $1,384,953$ & 947,672 & 963,666 & $1,316,424$ & $1,121,868$ & 653,643 & 477,407 & 388,465 \\
\hline 2008 & 417,567 & $1,091,452$ & $2,403,610$ & $1,851,372$ & 910,343 & 908,147 & $1,175,652$ & $1,230,900$ & 921,897 & 579,804 & 411,830 & 424,851 \\
\hline 2009 & 512,400 & $1,534,129$ & $2,409,767$ & $1,508,977$ & 914,728 & $1,081,327$ & $1,188,130$ & $1,245,172$ & 919,113 & 629,664 & 471,382 & 463,250 \\
\hline
\end{tabular}

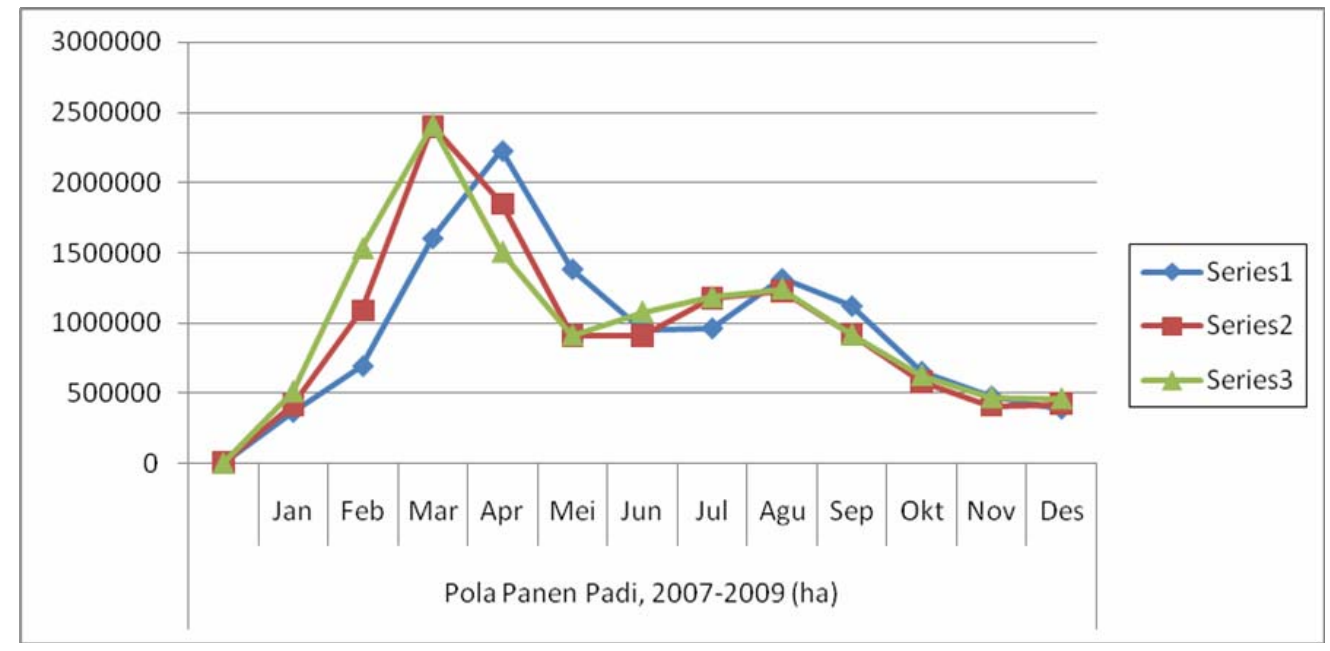

Gambar 1 Pola Panen Padi per Bulan dari Tahun 2007-2009

Dari grafik tersebut terlihat pola penen padi tidak mengalami peningkatan yang berarti, pola penen tersebut hanya mengalami sedikit peningkatan penurunan jika dibandingkan dengan bulan yang sama di tahun-tahun sebelumnya sehingga perlu dilakukan suatu usaha peningkatan produksi padi, karena peningkatan produksi lebih kecil dibandingkan dengan peningkatan jumlah penduduk Indonesia. Jika hal tersebut tidak dilakukan, maka Indonesia akan tergantung dengan impor beras, yang mengakibatkan dampak yang buruk bagi perekonomian serta kestabilan politik. 


\section{SIMPULAN}

Hingga saat ini lahan sawah tetap menjadi tulang punggung pengadaan produksi padi nasional. Hal ini terkait dengan tingkat kesuburan lahan, ketersediaan air, dan infrastruktur yang lebih baik serta pengelolaan lahan dan tanaman yang relatif lebih mudah di lahan sawah dibandingkan dengan agroekosistem lainnya. Oleh karena itu, program peningkatan produksi padi lebih diarahkan ke lahan sawah. Namun, saat ini sebagian lahan sawah mengalami penurunan produktivitas, sebagaimana tercermin dari pelandaian laju produksi padi.

Pada prinsipnya, pengelolaan tanaman, lahan, air, dan organisme pengganggu tumbuhan secara terpadu. Kombinasi teknologi pilihan yang penerapannya disesuaikan dengan kondisi dan potensi setempat untuk meningkatkan pendapatan petani melalui penerapan teknologi yang cocok untuk kondisi setempat sehingga dapat meningkatkan hasil gabah dan mutu beras serta menjaga kelestarian lingkungan.

Dengan asumsi tidak ada terobosan teknologi, produksi padi pada tahun 2020 diproyeksikan 57,4 juta ton. Jumlah penduduk Indonesia 262 juta jiwa dengan laju pertumbuhan penduduk 1, 27\% per tahun. Apabila konsumen beras per kapita masih tetap $134 \mathrm{~kg} /$ tahun, maka kebutuhan beras pada tahun 2020 mencapai 35,1 juta ton atau setara dengan 65,9 juta ton gabah kering giling. Jika produksi padi tidak meningkat, berarti pada tahun 2020 akan terjadi kekurangan beras sebanyak 4,5 juta ton atau setara derigan 8,5 juta ton gabah kering giling. Untuk mengatasi kekurangan pangan di masa mendatang tersebut perlu adanya terobosan peningkatan produksi padi. Kunci peningkatan produksi padi dengan efisiensi penggunaan pupuk berimbang spesifik lokasi yang cukup bagi pertumbuhan dan hasil tanaman. Peningkatan pendapatan petani tercapai apabila efisiensi penggunaan pupuk dapat dicapai. Pemupukan tanaman padi ditingkat petani masih bersifat umum belum memperhatikan status hara tanah dan kebutuhan hara tanaman.

Kondisi defisit beras diperburuk oleh konversi lahan subur (sawah irigasi dan tadah hujan) yang terus berlangsung di Jawa, sehingga pertumbuhan produksi padi cenderung menurun. Data statistik menunjukkan bahwa $95 \%$ dari produksi padi nasional berasal dari lahan sawah. Pertumbuhan penduduk dan perkembangan sektor industri dan perumahan menyebabkan peningkatan kebutuhan lahan untuk perumahan dan areal pabrik. Untuk itu harus ada upaya untuk tetap meningkatkan produksi padi, meskipun konversi lahan sawah subur (terutama di Jawa) sulit dicegah.

Teknologi pertanian juga dapat membantu para petani untuk memproduksi lebih banyak tanaman pangan dengan biaya produksi per hektar yang lebih rendah. Dengan membantu petani Indonesia untuk dapat mengakses inovasi seperti penggunaan variasi benih yag lebih baik dan produk pelindung tanaman, disertai dengan program edukasi dalam hal manajemen hama yang terintegrasi (Integrated Pest Management), juga penggunaan pelindung tanaman secara bertanggung jawab akan membantu peningkatan produksi lahan di Indonesia secara bekelanjutan.

Apabila kita bercermin pada kisah sukses pembangunan pertanian Jepang, Thailand, Korea Selatan, Taiwan, China dan Vietnam, semuanya tidak terlepas dan diawali dengan perombakan dan penataan kembali struktur panguasaan tanah yang timpang melalui program reformasi agraria. Sektor pertanian mendapat manfaat dari surplus yang diinvestasikan kepada sektor industri. Reformasi agraria sendiri mencakup redistribusi tanah kepada petani gurem dan buruh tani, penataan produksi melalui pembangunan infra struktur pertanian, fasilitas permodalan dan teknologi tepat guna, penguatan kelembagaan/organisasi petani dalam bentuk koperasi atau asosiasi petani, dan proteksi terhadap produk-produk pertanian. 


\section{DAFTAR PUSTAKA}

Administrasi Negara (LAN)-RI. (2001).

Adnyana, M. O. (2004). Analisis dampak dan strategi pengembangan peningkatan produktivitas padi dan ternak (P3T) ke depan. Makalah disampaikan pada Seminar Puslitbangtan 29 Januari 2004.

Arifin, B. (2001). Spektrum kebijakan pertanian Indonesia: Telaah struktur, kasus, dan alternatif strategi, Jakarta: Erlangga.

Badan Pusat Statistik (BPS). (1994, 1999, 2006). Luas lahan menurut penggunaan di Indonesia, Jakarta: Survai Pertanian, BPS.

Badan Pusat Statistik Indonesia (BPS). (1996, 2000, 2006), Jakarta: Statistik Indonesia, BPS.

Irawan. B. (2003). Konversi lahan sawah di Jawa dan dampaknya terhadap produksi padi (Land conversion in Java and its impact on rice production).

Kasryno. (1999). Ekonomi padi dan beras Indonesia (Indonesian rice economy). Indonesian Agency for Agricultural Research and Development, Jakarta, PAATP. Lokakarya Program Pengembanganh Manajemen.

Profitability of rice farming across production environments in Indonesia.

Sianipar, J. P. G., and H. M. Entang. (2001). Teknik-teknik analisis manajemen. Lembaga.

Sudaryanto, T., D. K. S Swastika, B. Sayaka., and S. Bahri. (2006). Financial and economic.

Suryana. A. (2002). Keragaan perberasan nasional, kebijakan perberasan di Asia. Regional Meeting in Bangkok, October 2002. 